\title{
Concepts and Capabilities of In-House Built Nanosecond Pulsed Electric Field (nsPEF) Generators for Electroporation: State of Art
}

\author{
Paulius Butkus *®D, Arūnas Murauskas, Sonata Tolvaišienė and Vitalij Novickij * \\ Department of Electrical Engineering, Faculty of Electronics, Vilnius Gediminas Technical University, \\ Sauletekio al. 11, 10221 Vilnius, Lithuania; arunas.murauskas@vgtu.lt (A.M.); sonata.tolvaisiene@vgtu.lt (S.T.) \\ * Correspondence: paulius.butkus@vgtu.lt (P.B.); vitalij.novickij@vgtu.lt (V.N.)
}

Received: 2 June 2020; Accepted: 18 June 2020; Published: 20 June 2020

\begin{abstract}
Electroporation is a pulsed electric field triggered phenomenon of cell permeabilization, which is extensively used in biomedical and biotechnological context. There is a growing scientific demand for high-voltage and/or high-frequency pulse generators for electropermeabilization of cells (electroporators). In the scope of this article we have reviewed the basic topologies of nanosecond pulsed electric field (nsPEF) generators for electroporation and the parametric capabilities of various in-house built devices, which were introduced in the last two decades. Classification of more than 60 various nsPEF generators was performed and pulse forming characteristics (pulse shape, voltage, duration and repetition frequency) were listed and compared. Lastly, the trends in the development of the electroporation technology were discussed.
\end{abstract}

Keywords: electroporation; electroporators; nanosecond pulsed electric fields; nsPEF; pulsed power devices; high frequency; MOSFET; capacitor discharge; Blumlein; high-voltage generators

\section{Introduction}

High intensity pulsed electric fields (PEF) can trigger increased permeability of biological cells to exogenous molecules to which the cells were initially impermeable [1]. PEF polarizes the cell membrane, which causes reorientation of lipids and formation of pores [2,3], thus increasing molecular transport across the cell membrane [4,5]. In case of reversible electroporation (depends on pulse parameters), the cell membrane is then resealed [6]. As a result, there is a variety of electroporation applications, which include cancer treatment [7], gene delivery [8], food processing [9], biorefinery [10] and many other [11,12]. In each case, various PEF parameters are required, which establishes a challenge in generator design in terms of universality. The straightforward distribution of applications in the pulse amplitude-duration space is summarized in Figure 1 [13-19].

It can be seen that the majority of applications lie in the micro-millisecond range. Indeed, the range of longer but lower amplitude pulses dominated the field for decades, however, in the recent years the number of works focusing shorter (nanosecond) pulses increased significantly. The reason lies in the limitations of conventional microsecond range methodologies such as bioimpedance-dependent field distribution [20], Joule heating [21], muscle contractions [22], electrical breakdown [23] and oxidative stress [24]. Nanosecond pulses cannot solve all the problems completely, however, in many cases the negative factors are diminished. However, state-of-art pulsed power electronics are required for generators to form pulses up to tens of $\mathrm{kV}$ and hundreds of amperes in the nanosecond range. Therefore, the price and engineering complexity of such generators is high, nevertheless, the trends in applications of nanosecond PEF make it viable (Figure 2). 


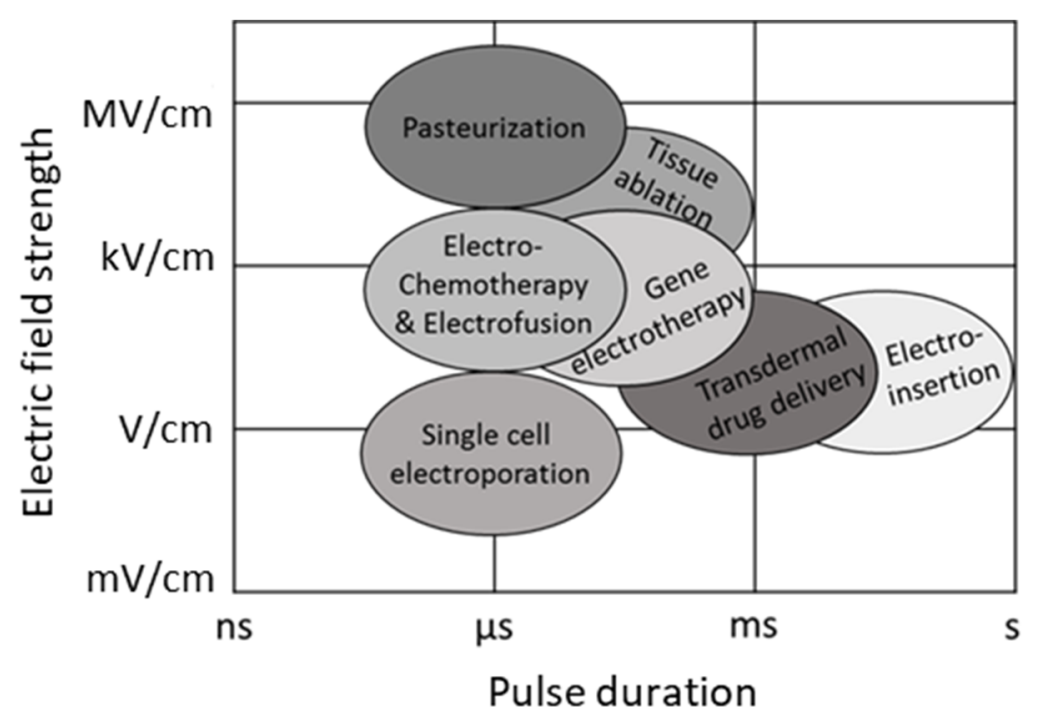

Figure 1. Generalized representation of pulse parameters for different electroporation applications.

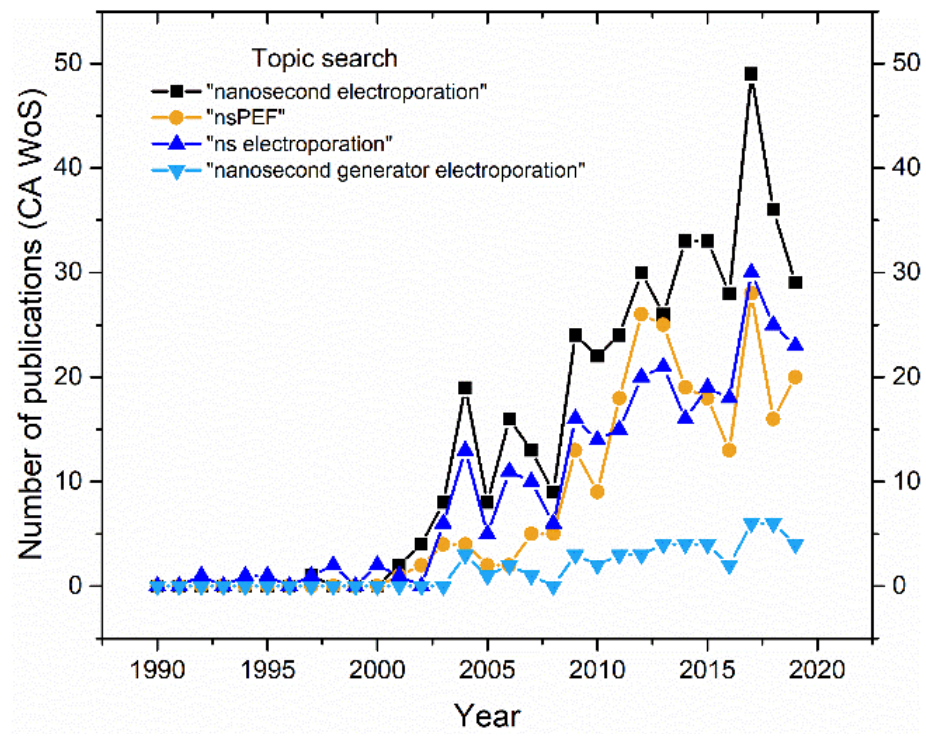

Figure 2. The trends in the number of publications on the topics of nanosecond electroporation according to Clarivate Analytics Web of Science (25 May 2020).

As it can be seen in Figure 2, there is a definitive rise in publications in the last decade, which partially is a consequence of better availability of pulse forming switches on the market. Development of laboratory grade generators for electroporation has intensified with the development of better semiconductors (i.e., silicon-carbide technology) [25]. Nevertheless, the number of papers focusing nanosecond pulse generators for electroporation is still low. A similar trend is observed in the frontier of short microsecond or sub-microsecond pulses using high frequency bursts (Figure 3), which possibly is a natural transition step from long micro-millisecond to the nanosecond range.

For the optimal effectiveness of the treatment many electroporation parameters must be adjusted, i.e., the pulse amplitude and duration, repetition frequency, waveform and number of pulses. As a result, universality of electroporators is important when a study of new phenomena and biological effects of PEF are established. 


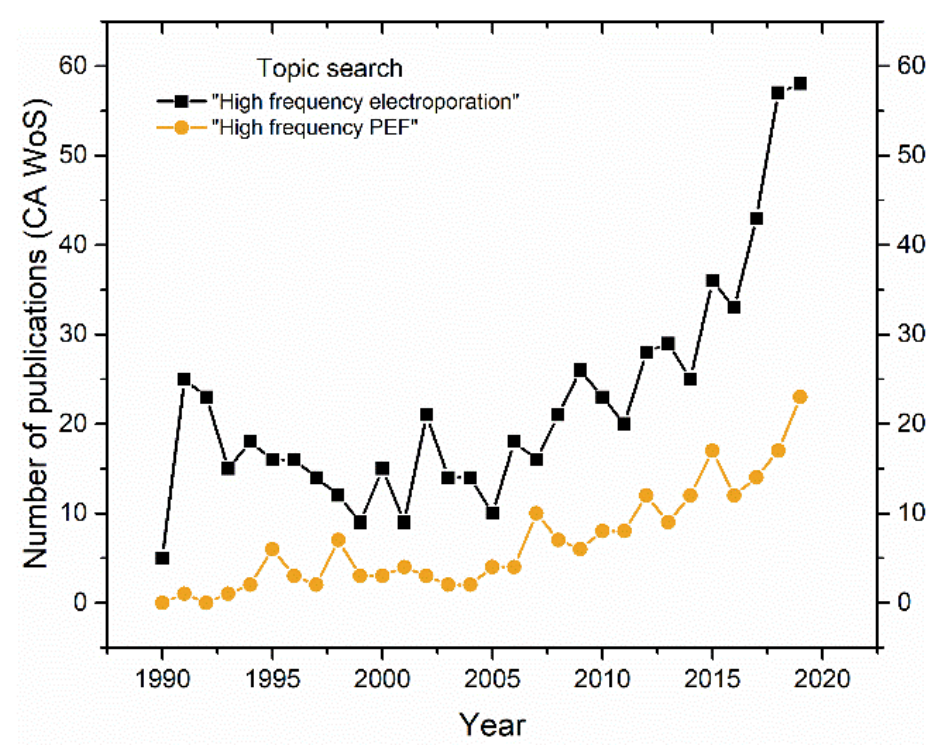

Figure 3. The trends in the number of publications on the topics of high frequency electroporation according to Clarivate Analytics Web of Science (25 May 2020).

There is high diversity of techniques used for the development of the PEF generators for electroporation applications. Some are well commercialized and a first comprehensive list of commercially available electroporators has been collected in 2004 [26], which was later updated in 2010 [15], 2017 [27] and 2019 [28]. It can be seen, that commercial approach had followed the most common demands of electroporation application. As a result, most of the commercial electroporators were developed with the pulse amplitude up to few $\mathrm{kV}$ and duration from tens of $\mu$ s to seconds. In comparison, the selection of commercial high-voltage nanosecond pulsed electric field (nsPEF) electroporators is significantly lower $[27,28]$.

Additionally, it is common, that the commercial devices have a limited range of available pulse durations and repetition frequencies, thus the device applicability is non-flexible. This is one of the main reasons, why the commercial electroporators are also not perfectly suited for electroporation research applications, where a wide parameters selection is desired. To sum up, the there is a growing scientific demand for nanosecond and high-frequency electroporators, which can, but are not limited, to deliver sub-microsecond range adjustable energy pulses. To cover the demand, the researchers develop in-house electroporators [29-33]. While the up to date review of commercial available PEF generators is available [27], there is no (at our knowledge) extensive overview of in-house built nanosecond and high-frequency electroporators. Currently, the works are mainly focused on the review of the general topologies used for generator design [28,30,34-40].

In the scope of this article, we reviewed the scientific papers reporting the developed nsPEF generators for electroporation in the last two decades. In addition, this article includes a summary and comparison of techniques used for the development of the PEF generator and the classification of generators is proposed based on the pulse forming circuit design. In total more than 60 in-house built nsPEF generators for electroporation applications were found, classified and compared.

\section{Basic Generator Topologies}

For electroporation research it is essential to have a pulse generator suitable to deliver controllable energy to biological tissue via application of repetitive electrical pulses with the predefined pulse waveform, voltage amplitude and pulse widths. The pulse forming circuits of the electroporator can be based on relatively simple circuits, which are discussed in the following works [15,26-28,34,38-42] and summarized in this section. The energy delivery can be provided by capacitor, inductor or transmission lines with the control of the switching element. These circuits can be enhanced by the application of 
modular approach, application of transformers, diodes or even by merging two concepts into a hybrid one. In this section, the common designs of pulse forming circuits used for electroporation application are presented and discussed.

\subsection{Pulse Forming Using Capacitor Discharge Circuits}

A direct capacitor discharge pulse forming circuit concept is one of the most common, simple and oldest concepts for PEF pulse forming [15,43]. It is based on the transfer of energy stored in the capacitors into the load throughout well-defined voltage pulses. The pulse delivery is normally controlled with a semiconductor switch. Depending on the switch type or driving mode, the waveform is either rectangular (using metal-oxide-semiconductor field-effect transistors (MOSFETs) and insulated-gate bipolar transistors (IGBTs) [44]) or exponential decay wave (older concept typically used with thyristors [45]). In case of exponential decay pulses, the duration of the pulse (decay time) is defined by RC parameters of the discharge circuit, while in the case of rectangular pulses the parameters are mostly limited by the switch capabilities and the discharge capacitor value. The principle pulse forming circuit of capacitor discharge pulse generator is represented in Figure 4.

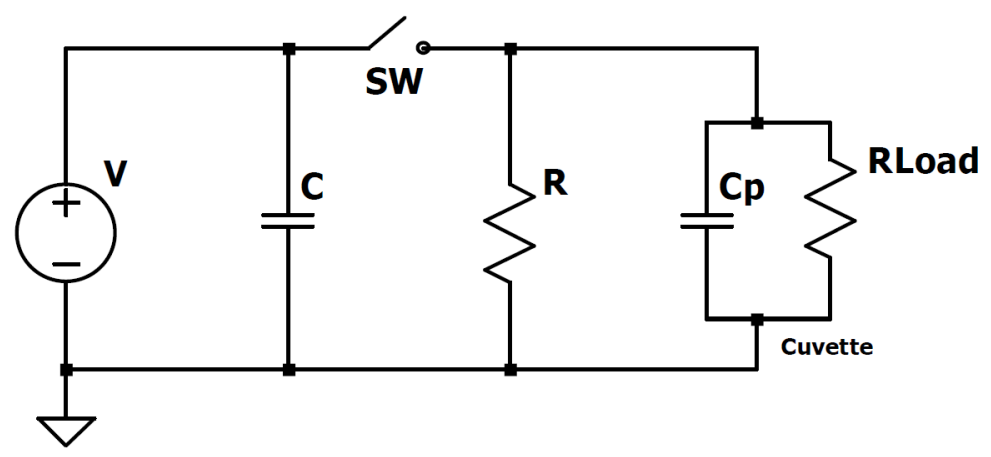

Figure 4. The principle circuit of a direct capacitor discharge pulse generator.

The pulse generator is composed of a variable high-voltage power supply $\mathrm{V}$, a discharge capacitor $\mathrm{C}$, a switch SW and optionally a resistor $\mathrm{R}$. The direct capacitor discharge topology benefits from a simple and inexpensive design $[38,43]$. However, to ensure the rectangular wave delivery and limiting the pulse amplitude droop, a high capacity ( $\mu \mathrm{F}$ to $\mathrm{mF}$ range) capacitor bank is required and the switch must withstand the full voltage amplitude. It limits the selection of available switches in case of high-voltage builds. In such a case, several series switches must be used, which results in increased complexity of the generator due to challenges in switch synchronization.

To overcome the limitations of the direct capacitor discharge concept, a more complex modular circuit topology can be used [46]. It provides voltage distribution between several switches and gives additional flexibility for the output pulse shape and amplitude. A simple example of a modular structure is presented in Figure 5.

The circuit includes several galvanically isolated high-voltage power supplies V1,2...n. Each is controlled individually and can be set to a different amplitude. The voltages of the individual circuits contribute to the generation of a single output pulse at any time. The output voltage will be the sum of the voltages from separate stages, so adjusting the output voltage is possible. However, many stages are required to have enough output voltage levels, which consequently increases the cost of the device [38,39].

The Marx generator is an example of a modular circuit, however, due to high applicability is often separated as an independent topology. Originally it was developed to test power grid high-voltage components and provide a capability to produce high-voltage pulses using a low-voltage DC supply. This topology has been adopted for PEF generation and widely used in electroporation applications $[30,31]$. The simplified circuit is represented in Figure 6. 


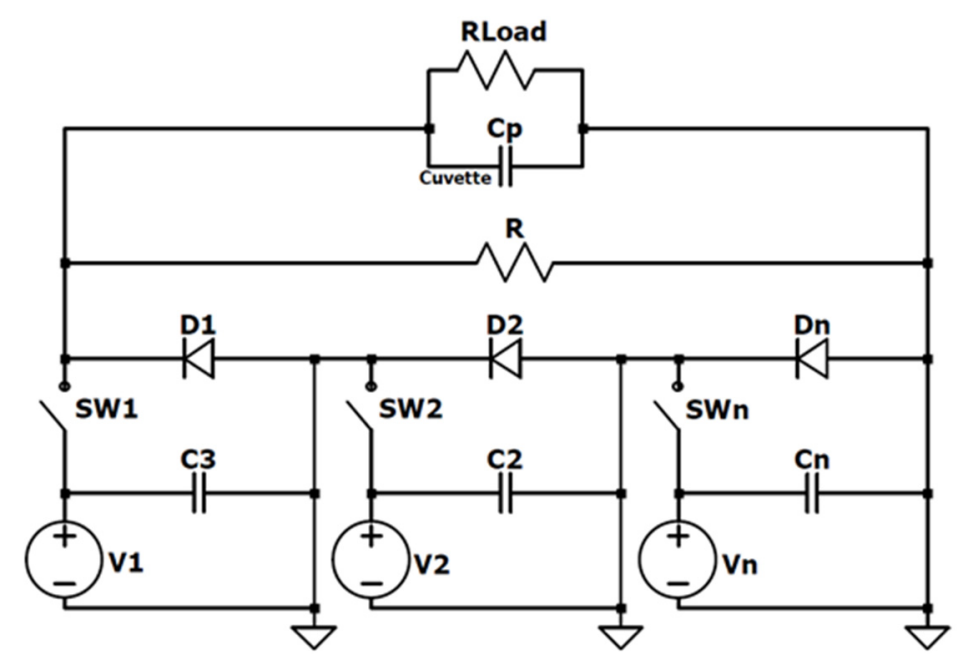

Figure 5. The principle circuit of modular direct capacitor discharge pulse generator.

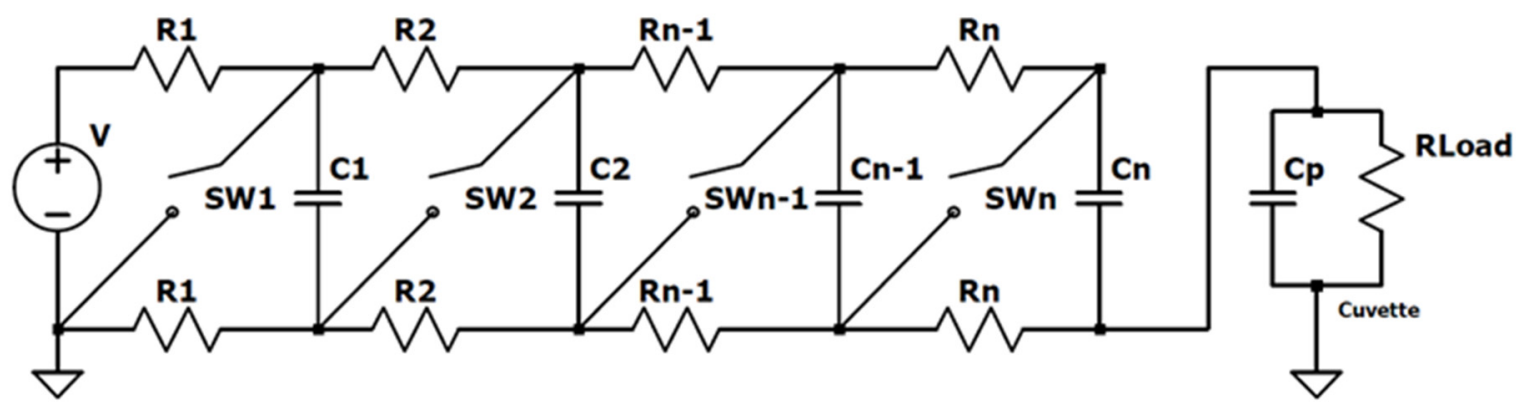

Figure 6. The circuit of pulse generator based on Marx topology.

The full Marx topology is based on separate stages/cells, where each stage has an energy storing capacitor $C$, a resistor $\mathrm{R}$ and a switch SW. The stages are charged in parallel from a direct current power supply $\mathrm{V}$ and subsequently connected in series with a load when the switches are triggered. In case of spark gaps the capacitors are fully discharged (decaying pulse), however the current and voltage flexibilities are high. For such a design, the pulse repetition rates are frequently in the order of several $\mathrm{Hz}$, but the total charging voltage can reach tens or even hundreds of $\mathrm{kV} \mathrm{[47-49].} \mathrm{The} \mathrm{voltage}$ levels between 50 and $100 \mathrm{kV}$ are most commonly used in industrial application [50-52]. In case when the semiconductor switches are used, a partial discharge of the capacitors can be achieved. The output voltages are frequently determined by the switch breakdown voltage and the number of stages, however, devices in the range of $1-6 \mathrm{kV}$ are common [31,39,53].

In case the bipolar pulses are required to optimize the electroporation applications (e.g., food products treatment) [54,55], the direct capacitor discharge pulse generator concept can be enhanced with half-bridge or full-bridge circuit [56] as presented in Figure 7.

In both cases the generator can produce positive and/or negative high-voltage pulses. However, the half bridge topology has limitations in operation with capacitive-type of loads, hence full-bridge concept is more common. The increase of the number of the switches in a full-bridge concept brings additional operational flexibility similarly to the direct capacitor discharge topology. Moreover, to enhance the pulse control and scalability several half-bridge or full-bridge pulse forming circuits can be stacked in a modular approach $[30,32,57]$. Additionally, Marx generators can be arranged in a bridge configuration to enable the generation of bipolar pulses $[30,31,58]$.

Nevertheless, independently on the topologies described above the capacitor discharge circuits are limited by switching dynamics of semiconductor devices, thus the minimal pulse durations are typically in the sub-microsecond range. In order to form shorter pulses (i.e., less than $100 \mathrm{~ns}$ ) other electroporator topologies are required. 


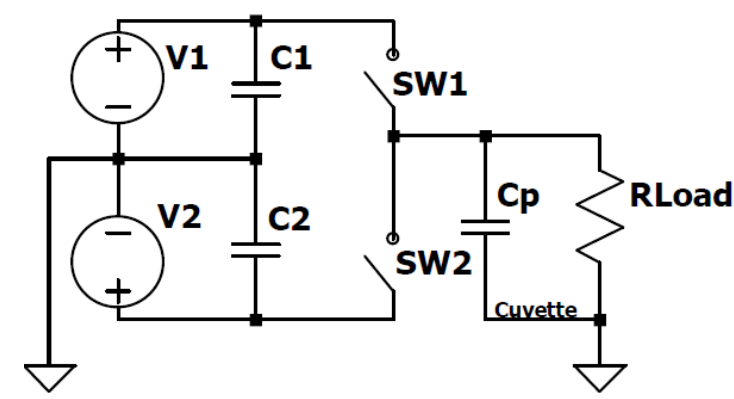

(a)

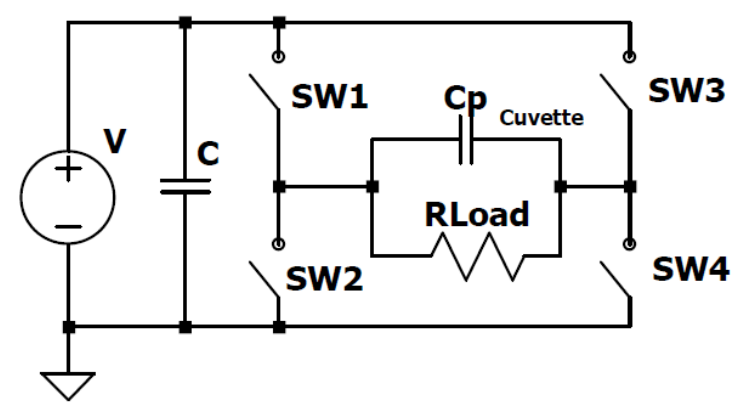

(b)

Figure 7. The conceptual circuit of bipolar half-bridge (a) and full-bridge (b) direct capacitor discharge pulse generator.

\subsection{Pulse Forming Circuit Topology Based on Transmission Lines}

The other group of pulse forming circuits is based on the charge and discharge of the transmission lines. This is a common type of circuit topology for generation of high-voltage pulses with less than 100 ns duration $[39,59]$. As illustrated in Figure 8, the pulse forming circuit is composed of coaxial cable, which is used as a conductor of length 1 and charged through a resistor $\mathrm{R}$ to a voltage $\mathrm{V}$. The transmission line discharge and pulse forming are controlled by the switch SW.

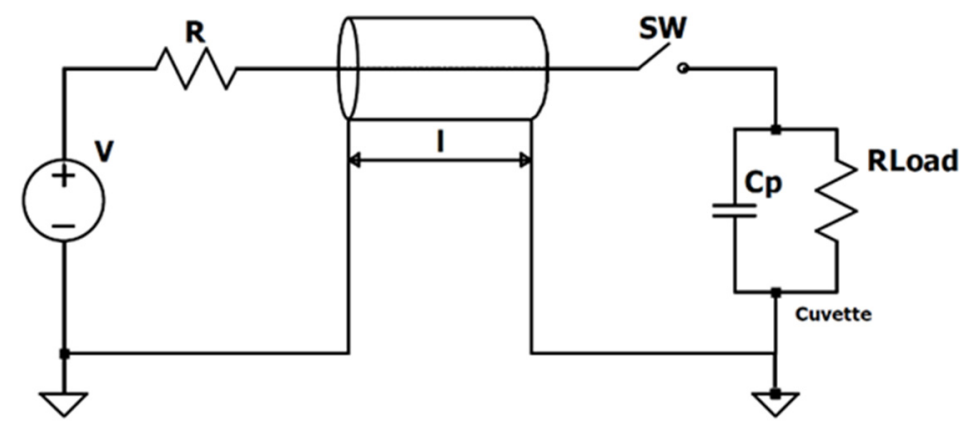

Figure 8. The conceptual circuit of a transmission line pulse generator.

In order to form rectangular pulses the impedance of the load must match the characteristic impedance of the transmission line. However, load matching requirement by design limits the generator's compatibility with dynamic loads since the impedance of the transmission line is dependent on the parameters of the cable.

The pulse amplitude of a single transmission line generator is limited to the half of the power supply voltage, while two or more lines must be used to match the pulse amplitude voltage to the power supply voltage (Figure 9). This type of configuration is known as a Blumlein transmission line pulse generator. Blumlein pulse generator is one of the most popular designs for the generation of rectangular high-voltage nsPEF pulses [60-62]. The generator is based on the two transmission lines of identical length 1 . Both transmission lines are electrically connected at one end to a load and discharged by closing the switch. If the load is mismatched (i.e., the load resistance is larger or smaller than the transmission line impedance), reflections of the voltage step at the load and at the open end of the transmission line will lead to a strain of consecutive decaying pulses [42,63,64]. Hence, to generate rectangular wave pulse without any pulse reflections, the impedance of the load must be twice the impedance of the transmission line. This is not always an easy task to achieve, since the electrical impedance of biological tissue is often unknown, can vary from sample to sample and can be even dynamic during the pulse delivery $[38,65]$. 


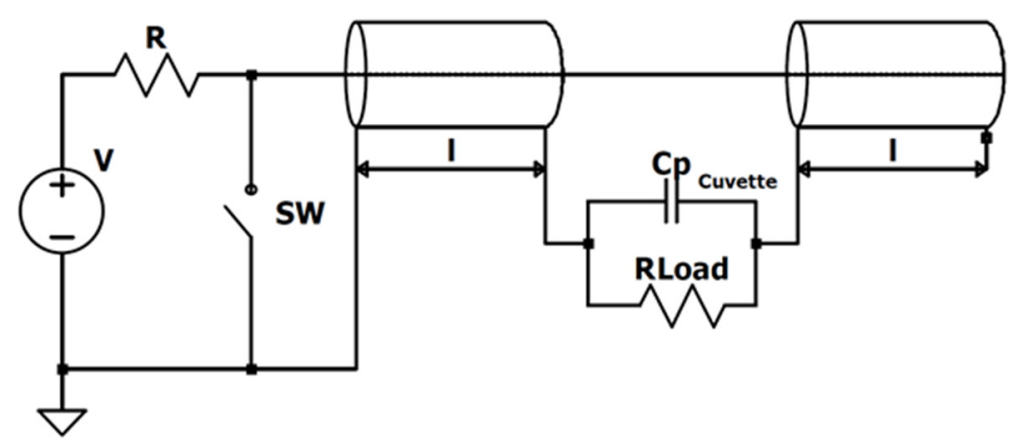

Figure 9. The conceptual circuit of a Blumlein pulse generator.

Lastly, the control of pulse duration in a Blumlein circuit is non-flexible. It is defined by the length of the transmission line and the dielectric between the conductors, while the switch-off time determines the rise time of the generated voltage pulse. When the switch is closed, a voltage pulse is generated across the load for the time it takes the voltage step to propagate along the transmission line [42]. The switching element must withstand full high-voltage, which can be a challenge. On the other hand, in case of a spark gap switch, the output amplitudes can reach tens or hundreds of $\mathrm{kV}$ and a few $\mathrm{kA}$.

Lastly, the Blumlein generators are large dimension devices and have high demands for the electrical components. The usual concepts have a relatively short lifetime and operate in low repetition rate, while a rectangular wave pulse is typically delivered with a jitter $[38,63]$. However, with the latest modifications, Blumlein generators can now generate also a high-frequency (range of up to few $\mathrm{MHz}$ ) output pulses with variable duration, amplitude and even polarity $[38,60,63,66]$.

\subsection{The Inductive Energy Discharge Pulse Generators}

The third group of pulse generators is based on inductive energy discharge circuits, which transfer energy stored in the magnetic fields of coils into well-defined voltage pulses. The circuit concept is shown in Figure 10.

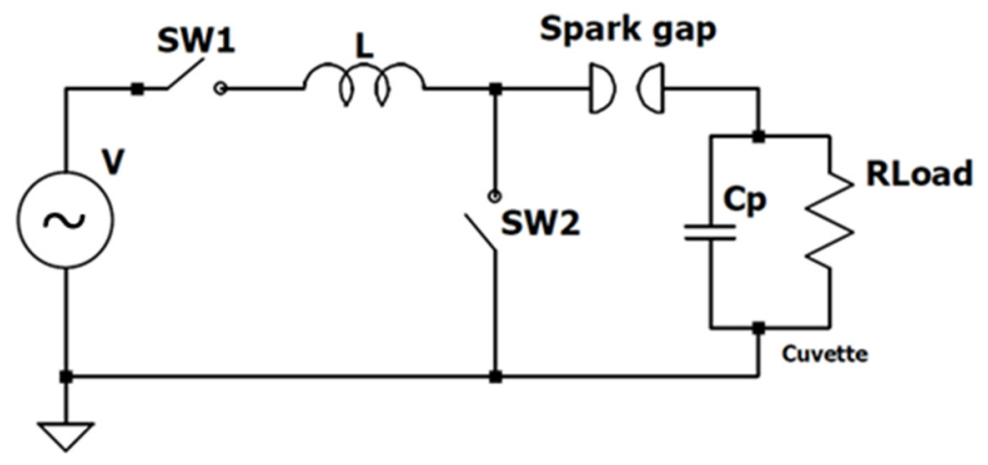

Figure 10. The conceptual circuit of an inductive energy discharge pulse generator.

The generator uses an AC power supply, a low voltage capacitor bank $C$ for a primary electric energy storage and an inductor for secondary magnetic energy storage. When the switch SW1 is closed, the electric energy is discharged from the capacitor bank $C$ into the inductor $L$. Hence, during the first quarter period of the sinusoidal AC-current, the magnetic energy stored in the inductor increases and the electric energy stored in the capacitor bank decreases. At the peak of sinusoidal current, the magnetic energy stored in the inductor reaches its maximum. At this point, the opening switch SW2 is activated and the current is abruptly interrupted influencing high rate of change of the magnetic flux $(\mathrm{dB} / \mathrm{dt})$. Such a transient process induces voltage in the inductor, which is further discharged by a spark gap through the load [67].

The inductive energy discharge pulse generator has many drawbacks and is not used for electroporation research. Instead, improved circuits are applied (i.e., the diode opening switch (DOS) 
topology). This is a commonly used concept for generation of high voltage (several $\mathrm{kV}$ ) pulses in the nanosecond range [29]. The diode opening switch circuit is presented in Figure 11.

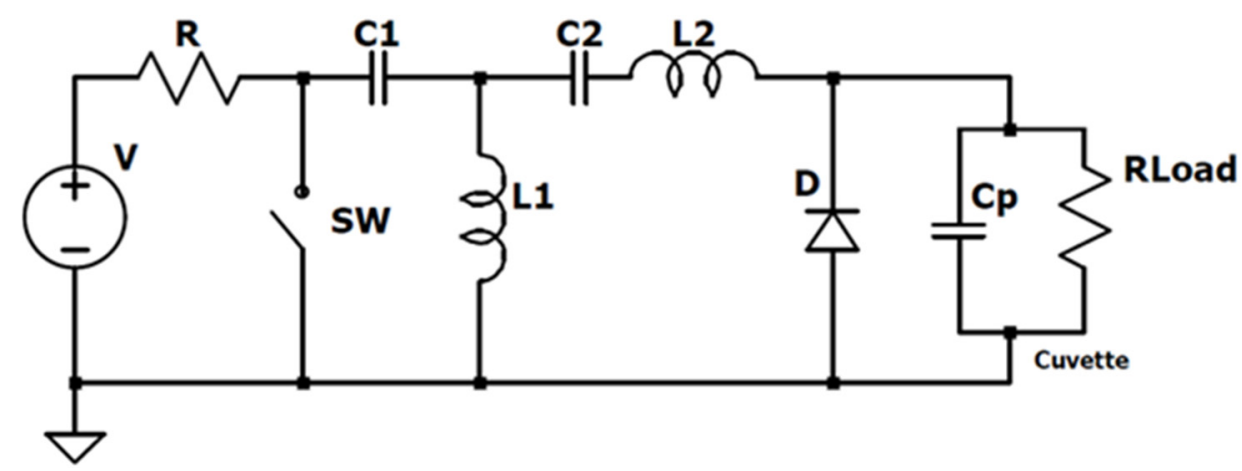

Figure 11. The circuit of a diode opening switch generator.

The diode opening switch circuit is based on the DC voltage power supply V, which charges the capacitor bank $\mathrm{C} 1$ through the resistor $\mathrm{R}$. When the capacitor is fully charged, the switch $\mathrm{SW}$ is closed and the energy in the capacitor C1 starts circulating in the resonant network (C1, C2, L1 and L2). After completing half of the period, the resonant network starts pumping the current through the diodes in the reverse direction. Ideally, the diode abruptly stops conducting and commutates the L2 current into the load. Therefore, this type of circuit is based on the saved energy transfer from inductor L2 to the load with a good repeatability [29].

Beside the application of diodes, it is also common that the inductive energy discharge pulse generator can be improved with the step-up pulse transformer. In this case the amplitude of the voltage pulse did not affect the opening switch [39]. A simplified transformer-based pulse forming circuit is presented in Figure 12.

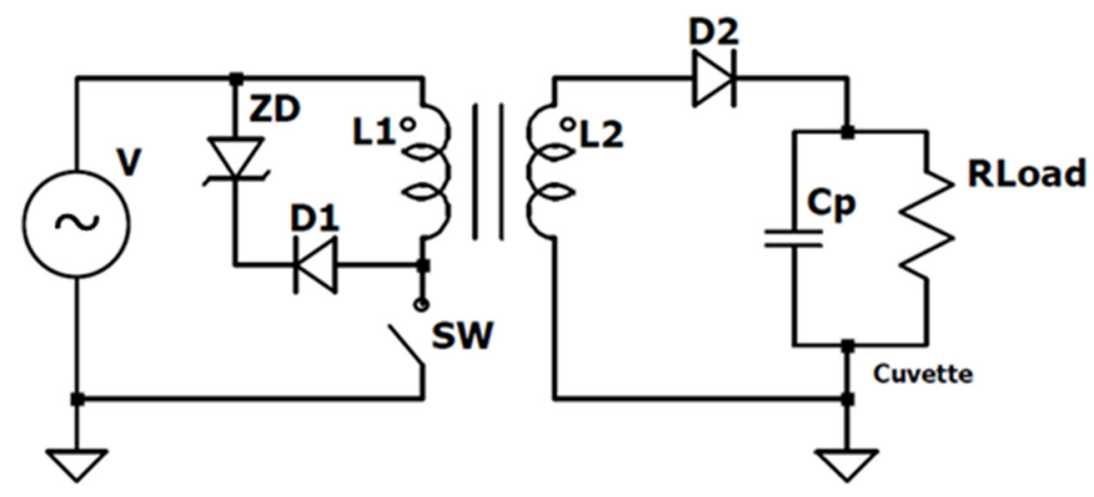

Figure 12. The conceptual circuit of a transformers-based pulse generator.

Despite the advantages, the transformer-based pulse generator also has several issues, like core saturation, reset time after pulse delivery and distorted pulse shape because of the parasitic circuit elements. All these issues must be considered during the design of the pulse forming circuit [39]. On the other hand, the transformer based topology can be combined with the modular approach discussed before providing additional flexibility and pulse control [68].

\section{Overview}

\subsection{Advantages and Disadvantages of the Typical Electroporator Concepts}

The presented concepts of pulse generators demonstrate the diversity of techniques used for high-voltage pulse generation suitable for electroporation applications. All the techniques are summarized in the Figure 13. 


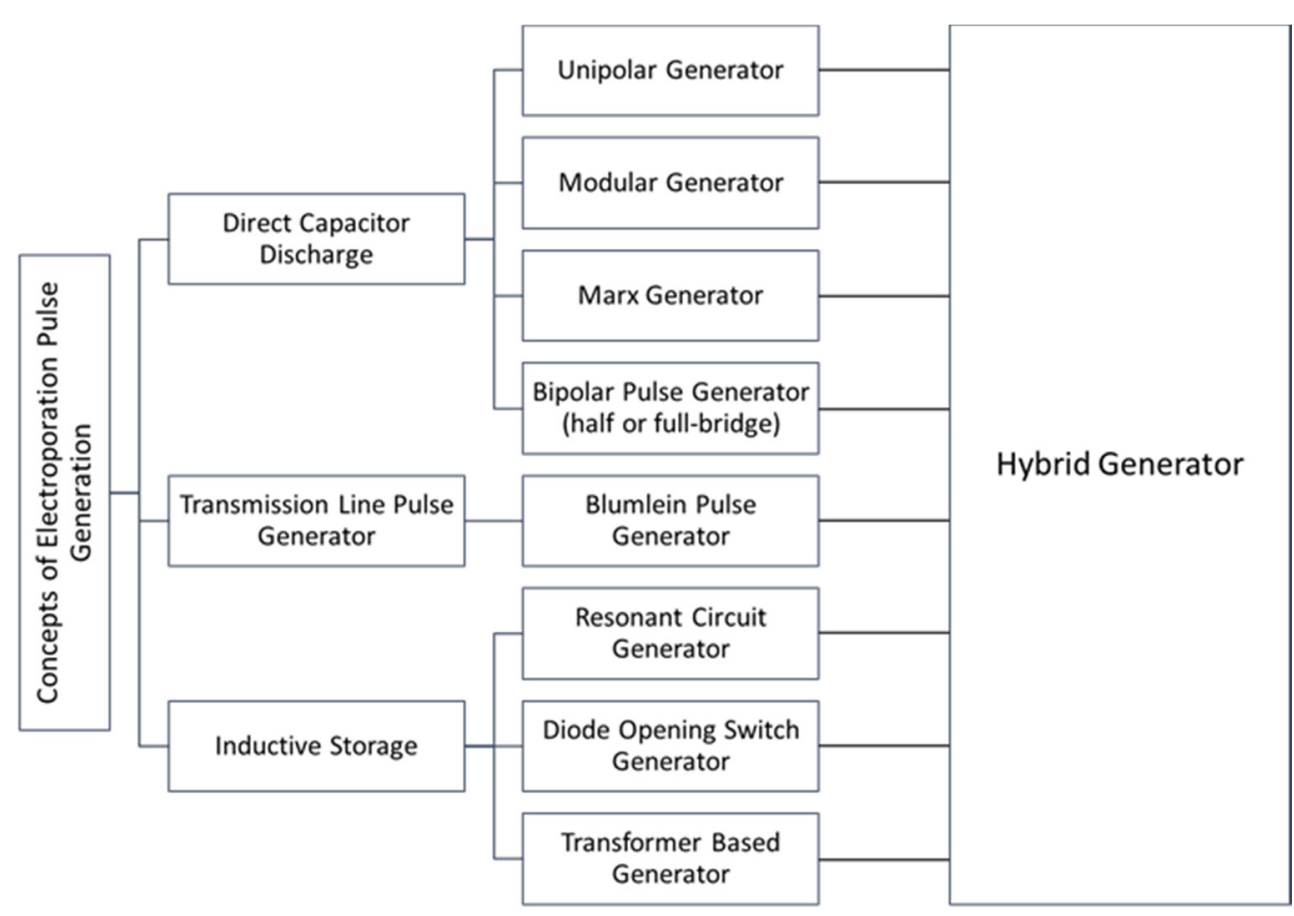

Figure 13. The diversity of pulse generators topologies for electroporation applications.

Based on the energy storage, the pulse generators can be divided into three main groups: direct capacitor discharge, transmission line discharge and inductive storage discharge. Each has advantages and disadvantages, which are summarized in the Table 1.

Further, the in-house built nsPEF generators were analyzed and classified based on the switching type. The review focused only on nsPEF pulse generators, which were reported specifically for the application in the field of electroporation. We have included only the references where the reported duration of the pulse is in the sub-microsecond range (below $1 \mu \mathrm{s}$ ). In total $63 \mathrm{nsPEF}$ generators for electroporation matched the requirements and are listed in Table 2. The devices are grouped based on the pulse forming circuit with the following parameters reported: pulse form, pulse duration, maximum pulse amplitude, pulse repetition frequency, switch type, switch model and additional remarks on the pulse form and topology in case the divergence from the usual performance is noticed. 
Table 1. The comparison between the topologies of pulse generators used for electroporation.

\begin{tabular}{|c|c|c|c|}
\hline & Concept & Advantage & Disadvantage \\
\hline \multirow{4}{*}{ Direct Capacitor } & Non-Modular & $\begin{array}{l}\text { Simple and inexpensive construction for systems up to } 1 \mathrm{kV} \text {; } \\
\text { Very flexible pulse shape control in the } \\
\text { sub-microsecond-millisecond range; } \\
\text { Can operate in a high frequency range. }\end{array}$ & $\begin{array}{l}\text { High-voltage supply required; } \\
\text { Amplitude droop during the pulse; } \\
\text { High capacity capacitor banks are required for rectangular } \\
\text { wave delivery into high loads; } \\
\text { Switch must withstand full voltage amplitude or complex } \\
\text { synchronization circuits are required in case of array } \\
\text { of switches; } \\
\text { Not suitable for sub-100 ns pulses. }\end{array}$ \\
\hline & Bipolar & $\begin{array}{l}\text { Positive and/or negative high-voltage pulses; } \\
\text { Highest pulse forming flexibility; } \\
\text { Capability to use asymmetrical pulses; } \\
\text { Specific electrotransfer mechanisms can be triggered. }\end{array}$ & $\begin{array}{l}\text { Switch synchronization is needed; } \\
\text { Complex control systems; } \\
\text { Limited voltage handling capability; } \\
\text { Not suitable for sub-100 ns pulses. }\end{array}$ \\
\hline & Modular & $\begin{array}{l}\text { Applicable with low voltage switches and voltage supplies; } \\
\text { Wide flexibility of pulse parameters; } \\
\text { Arbitrary signal shape; } \\
\text { Easy to achieve high currents; } \\
\text { Can operate in high frequency range. }\end{array}$ & $\begin{array}{l}\text { Limited amplitude resolution; } \\
\text { Complex control system; } \\
\text { Switch synchronization is needed; } \\
\text { Not suitable for sub-100 ns pulses. }\end{array}$ \\
\hline & Marx Generator & $\begin{array}{l}\text { Applicable with low voltage switches and voltage supplies; } \\
\text { High voltages up to hundreds of } \mathrm{kV} ; \\
\text { High currents; } \\
\text { Can generate sub-100 ns pulses. }\end{array}$ & $\begin{array}{l}\text { Bulky structure; } \\
\text { Voltage droop is common when high loads are used; } \\
\text { Limited high frequency capability; } \\
\text { Electrode degradation in case of spark-gaps. }\end{array}$ \\
\hline Transmission line & Blumlein & $\begin{array}{l}\text { Simple design; } \\
\text { Commonly used for short pulse generation (sub-100 ns); } \\
\text { High-voltages and currents; } \\
\text { Can be used for bipolar pulses }\end{array}$ & $\begin{array}{l}\text { Load impedance matching requirement; } \\
\text { Pulse width inflexibility (limited to transmission line); } \\
\text { Relatively short lifetime; } \\
\text { Most of the usual concepts operate in low repetition rate; } \\
\text { Big dimensions of the generator. }\end{array}$ \\
\hline \multirow{3}{*}{ Inductive Storage } & Resonant Circuit & High energy density pulsing can be ensured. & $\begin{array}{l}\text { Not applicable for electroporation directly; } \\
\text { Parasitic parameters affect the waveform; } \\
\text { Switch synchronization is needed; } \\
\text { Complex control system. }\end{array}$ \\
\hline & Diode Opening Switch & $\begin{array}{l}\text { High energy density; } \\
\text { Accessible electrical components; } \\
\text { Variable load impedance; } \\
\text { Commonly used for short pulse generation (sub-100 ns); } \\
\text { Fast repetition frequency. }\end{array}$ & $\begin{array}{l}\text { Complicated design; } \\
\text { Low output power; } \\
\text { Switch synchronization is needed; } \\
\text { Complex control system; } \\
\text { Complex switching and poor control of pulse durations. }\end{array}$ \\
\hline & Transformer based & $\begin{array}{l}\text { High pulse amplitude; } \\
\text { Applicable with low voltage switches; } \\
\text { Flexible pulse amplitude. }\end{array}$ & $\begin{array}{l}\text { Transient processes affect pulse waveform; } \\
\text { Core saturation and reset after pulse. }\end{array}$ \\
\hline
\end{tabular}


Table 2. List of in-house developed nanosecond pulsed electric field (nsPEF) generators with their and pulse parameters for electroporation application.

\begin{tabular}{|c|c|c|c|c|c|c|c|c|c|}
\hline Circuit & Reference & Pulse Form & Pulse Polarity & Pulse Duration & $\begin{array}{l}\text { Maximum } \\
\text { Amplitude }\end{array}$ & $\begin{array}{l}\text { Repetition } \\
\text { Frequency }\end{array}$ & Switch & Switch Model & $\begin{array}{l}\text { Pulse Form and } \\
\text { Topology Remarks }\end{array}$ \\
\hline \multirow{16}{*}{ 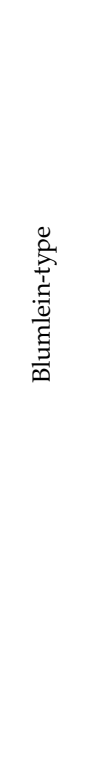 } & $2000[73]$ & Gaussian & Unipolar & $8 \mathrm{~ns}$ & $30 \mathrm{kV}$ & - & Spark gap & - & Pressurized spark gap \\
\hline & $2003[40]$ & Gaussian & Unipolar & $3-15 \mathrm{~ns}$ & $>10 \mathrm{kV}$ & - & Spark gap & - & Distorted pulse shape \\
\hline & $2006[64]$ & Rectangular & Unipolar & $10 \mathrm{~ns}$ & $40 \mathrm{kV}$ & - & Spark gap & - & Distorted pulse shape \\
\hline & $2006[64]$ & Rectangular & Unipolar & $10-300 \mathrm{~ns}$ & $1 \mathrm{kV}$ & $0-50 \mathrm{MHz}$ & MOSFET & DE375-102N12A & - \\
\hline & $2007[48]$ & Gaussian & Unipolar & $50 \mathrm{~ns}$ & $65 \mathrm{kV}$ & $10 \mathrm{~Hz}$ & Spark gap & - & Distorted pulse shape \\
\hline & 2008 [74] & Rectangular & Unipolar & $8-300 \mathrm{~ns}$ & $1 \mathrm{kV}$ & - & MOSFET & DE275-102N06A & - \\
\hline & 2009 [66] & Rectangular & Unipolar and bipolar & $20,50,75,150$, and $230 \mathrm{~ns}$ & $<0.3 \mathrm{kV}$ & $0-1.1 \mathrm{MHz}$ & MOSFET & DE275-102N06A & High pulse amplitude droop \\
\hline & 2011 [75] & - & - & $40-200 \mathrm{~ns}$ & $1 \mathrm{kV}$ & $0-100 \mathrm{kHz}$ & - & - & Pulse shape not specified \\
\hline & 2013 [63] & Gaussian & Unipolar and bipolar & $10,20,60 \mathrm{~ns}$ & $2 \mathrm{kV}$ & - & Transistor & HTS-UF & Distorted pulse shape \\
\hline & 2014 [76] & Gaussian & Bipolar & $2 \mathrm{~ns}$ & $650 \mathrm{kV}$ & - & Oil switch & - & Hybrid with resonant \\
\hline & 2016 [60] & Rectangular & Unipolar & $50-100 \mathrm{~ns}$ & $2 \mathrm{kV}$ & $0-(\sim 3) \mathrm{kHz}$ & MOSFET & DE475-102N21A & Distorted pulse shape \\
\hline & 2016 [61] & Rectangular & Unipolar & $100 \mathrm{~ns}$ & $1.7 \mathrm{kV}$ & $0-(\sim 3) \mathrm{kHz}$ & MOSFET & - & $\begin{array}{c}\text { Distorted pulse shape; Modular } \\
\text { circuit }\end{array}$ \\
\hline & 2017 [62] & Gaussian & Unipolar & $20 \mathrm{~ns}$ & $2.5 \mathrm{kV}$ & $0-10 \mathrm{kHz}$ & MOSFET & DE475-102N21A & - \\
\hline & 2018 [77] & Gaussian & Unipolar and bipolar & $30 \mathrm{~ns}$ & $10 \mathrm{kV}$ & $0-200 \mathrm{kHz}$ & MOSFET & DE475-102N21A & Modular \\
\hline & 2019 [78] & Rectangular & Unipolar & $30 \mathrm{~ns}$ & $4 \mathrm{kV}$ & $1 \mathrm{kHz}$ & IGBT and spark gap & IRG4PH50K & $\begin{array}{l}\text { Distorted pulse shape; With } \\
\text { transformer }\end{array}$ \\
\hline & 2020 [79] & Rectangular & Unipolar & $5 \mathrm{~ns}$ & $0.5 \mathrm{kV}$ & $0-10 \mathrm{MHz}$ & MOSFET & IXZ631DF12N100 & Fixed pulse duration; \\
\hline
\end{tabular}


Table 2. Cont

\begin{tabular}{|c|c|c|c|c|c|c|c|c|c|}
\hline Circuit & Reference & Pulse Form & Pulse Polarity & Pulse Duration & $\begin{array}{l}\text { Maximum } \\
\text { Amplitude }\end{array}$ & $\begin{array}{l}\text { Repetition } \\
\text { Frequency }\end{array}$ & Switch & Switch Model & $\begin{array}{c}\text { Pulse Form and } \\
\text { Topology Remarks }\end{array}$ \\
\hline \multirow{5}{*}{ 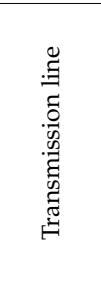 } & $2003[40]$ & Gaussian & Unipolar & $150 \mathrm{~ns}$ & $12 \mathrm{kV}$ & - & Spark gap & - & Distorted pulse shape \\
\hline & $2010[80]$ & Rectangular & Bipolar & $2 \mathrm{~ns}$ & $1.6 \mathrm{kV}$ & $0-10 \mathrm{~Hz}$ & PCSS $^{1}$ & - & $\begin{array}{l}\text { Distorted pulse shape and laser } \\
\text { triggering }\end{array}$ \\
\hline & 2013 [81] & Rectangular & Bipolar & $10,40,60,92 \mathrm{~ns}$ & $12.5 \mathrm{kV}$ & - & Spark gap & - & Laser triggering \\
\hline & 2018 [36] & Rectangular & Bipolar & $10,60,300 \mathrm{~ns}$ & $10 \mathrm{kV}$ & - & Spark gap & - & $\begin{array}{l}\text { Distorted pulse shape; Hybrid } \\
\text { with resonant circuit }\end{array}$ \\
\hline & 2019 [59] & Rectangular & Unipolar & $120,160,200,300,400 \mathrm{~ns}$ & $10 \mathrm{kV}$ & - & Spark gap & - & Distorted pulse shape \\
\hline \multirow{11}{*}{ 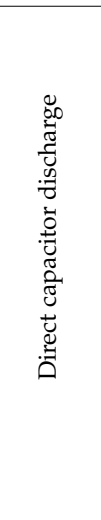 } & $2001[49]$ & Gaussian & Unipolar & $2 \mathrm{~ns}$ & $2.6 \mathrm{kV}$ & - & Spark gap & - & Distorted pulse shape \\
\hline & 2003 [40] & Rectangular & Unipolar & $12 \mathrm{~ns}$ & $1 \mathrm{kV}$ & - & MOSFET & DE275-501N16A & Distorted pulse shape \\
\hline & 2004 [82] & Rectangular & Unipolar & $75 \mathrm{~ns}$ to $10 \mathrm{~ms}$ & $0.400 \mathrm{kV}$ & $600 \mathrm{kHz}$ & MOSFET & $\begin{array}{c}\text { IXYSRF } \\
\text { DE275-501N16A }\end{array}$ & - \\
\hline & 2004 [83] & Exponential & Unipolar & $100 \mathrm{~ns}$ to $100 \mu \mathrm{s}$ & $0.3 \mathrm{kV}$ & $0-2 \mathrm{kHz}$ & IGBT & - & - \\
\hline & $2004[84]$ & Exponential & Unipolar & - & $3.4 \mathrm{kV}$ & $0-1 \mathrm{kHz}$ & BJTs & ZTX415 & Pulse rise time to $2 \mathrm{~ns}$ \\
\hline & 2012 [85] & Gaussian & Bipolar & $2.5 \mathrm{~ns}$ & $1.66 \mathrm{kV}$ & - & Optoelectronic & - & - \\
\hline & 2014 [71] & Rectangular & Unipolar & $200 \mathrm{~ns}$ to $5 \mu \mathrm{s}$ & $8 \mathrm{kV}$ & $0-30 \mathrm{~Hz}$ & MOSFET & HTS 91-12 & - \\
\hline & 2015 [86] & Rectangular & Unipolar & $38 \mathrm{~ns}$ to $7 \mu \mathrm{s}$ & $0.5 \mathrm{kV}$ & - & MOSFET & IRF740 & - \\
\hline & $2016[87]$ & Rectangular & Unipolar & $100 \mathrm{~ns}$ to $1 \mathrm{~ms}$ & $3 \mathrm{kV}$ & $0-1 \mathrm{MHz}$ & MOSFET & C2M0080120D & - \\
\hline & 2019 [72] & Rectangular & Unipolar & $80 \mathrm{~ns}$ to $1 \mu \mathrm{s}$ & $1.4 \mathrm{kV}$ & $0-50 \mathrm{~Hz}$ & MOSFET & C2M1000170D & - \\
\hline & $2019[88]$ & Rectangular & Unipolar & $80 \mathrm{~ns}$ & $0.5 \mathrm{kV}$ & - & MOSFET & - & - \\
\hline \multirow{4}{*}{ 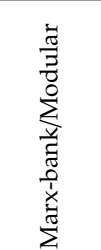 } & 2001 [49] & Gaussian & Unipolar & $6 \mathrm{~ns}$ & $6 \mathrm{kV}$ & - & $\begin{array}{l}\text { Spark gap and } \\
\text { MOSFET }\end{array}$ & $40 \mathrm{~N} 160$ & Distorted pulse shape \\
\hline & $2007[48]$ & Gaussian & Unipolar & $200 \mathrm{~ns}$ & $6 \mathrm{kV}$ & - & Spark gap & - & Single pulse \\
\hline & 2007 [89] & Gaussian & Unipolar & $1.3 \mathrm{~ns}$ & $1.1 \mathrm{kV}$ & $0-200 \mathrm{kHz}$ & Diode opening & $\begin{array}{l}\text { SOT-23 Zetex } \\
\text { FMMT417 }\end{array}$ & - \\
\hline & 2008 [47] & Gaussian & Unipolar & $135-220 \mathrm{ps}$ & $20-120 \mathrm{kV}$ & $0-15 \mathrm{~Hz}$ & Peaking & - & - \\
\hline
\end{tabular}


Table 2. Cont

\begin{tabular}{|c|c|c|c|c|c|c|c|c|c|}
\hline Circuit & Reference & Pulse Form & Pulse Polarity & Pulse Duration & $\begin{array}{l}\text { Maximum } \\
\text { Amplitude }\end{array}$ & $\begin{array}{l}\text { Repetition } \\
\text { Frequency }\end{array}$ & Switch & Switch Model & $\begin{array}{l}\text { Pulse Form and } \\
\text { Topology Remarks }\end{array}$ \\
\hline \multirow{19}{*}{ 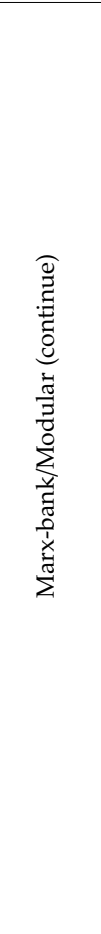 } & $2011[90]$ & Rectangular & Bipolar & $100 \mathrm{~ns}$ & $1 \mathrm{kV}$ & $1 \mathrm{kHz}$ & MOSFET and JFET $^{2}$ & - & $\begin{array}{l}\text { Hybrid with Blumlein; Distorted } \\
\text { pulse shape }\end{array}$ \\
\hline & 2012 [91] & Rectangular & Unipolar & $200 \mathrm{~ns}$ to $1 \mu \mathrm{s}$ & $8 \mathrm{kV}$ & $0-1 \mathrm{kHz}$ & MOSFET & - & - \\
\hline & 2013 [92] & Rectangular & Bipolar & $300 \mathrm{~ns}$ to $10 \mu \mathrm{s}$ & $4 \mathrm{kV}$ & $0-40 \mathrm{kHz}$ & IGBT & IRGPS60B120KDP & - \\
\hline & 2015 [93] & Gaussian & Unipolar & $600 \mathrm{ps}$ & $31.2 \mathrm{kV}$ & - & Spark gap & - & Distorted pulse shape \\
\hline & $2016[94]$ & Rectangular & Unipolar & $100 \mathrm{~ns}$ to $1 \mu \mathrm{s}$ & $8 \mathrm{kV}$ & $0-1 \mathrm{kHz}$ & MOSFET & C2M0080120D & - \\
\hline & 2016 [95] & Gaussian & Unipolar & $620 \mathrm{ps}$ & $1 \mathrm{kV}$ & $10 \mathrm{kHz}$ & Avalanche transistors & FMMT417 & $\begin{array}{l}\text { Hybrid with microstrip } \\
\text { transmission line }\end{array}$ \\
\hline & 2016 [96] & Rectangular & Unipolar & 200 ns to $100 \mu \mathrm{s}$ & $10 \mathrm{kV}$ & $0-1 \mathrm{kHz}$ & MOSFET & C2M0280120D & - \\
\hline & 2016 [97] & Rectangular & Bipolar & $100 \mathrm{~ns}$ to $1 \mu \mathrm{s}$ & $3 \mathrm{kV}$ & $0-1 \mathrm{kHz}$ & MOSFET & C2M0080120D & Voltage droop \\
\hline & $2016[98]$ & Rectangular & Unipolar and bipolar & $100 \mathrm{~ns}$ to $100 \mu \mathrm{s}$ & $3 \mathrm{kV}$ & $0-2 \mathrm{MHz}$ & MOSFET & C2M0080120D & - \\
\hline & 2017 [99] & Gaussian & Unipolar & $300 \mathrm{ps}$ & $1.6 \mathrm{kV}$ & $0-10 \mathrm{kHz}$ & Avalanche transistors & FMMT417 & Marx with gradient transmission \\
\hline & $2017[58]$ & Rectangular & Bipolar & $100 \mathrm{~ns}$ to $1 \mu \mathrm{s}$ & $3 \mathrm{kV}$ & $1 \mathrm{kHz}$ & MOSFET & C2M0080120D & - \\
\hline & 2017 [100] & Gaussian & Unipolar & $400 \mathrm{~ns}$ to $20 \mu \mathrm{s}$ & $6 \mathrm{kV}$ & $0-100 \mathrm{MHz}$ & IGBT & IXYK 120N120C & - \\
\hline & $2018[101]$ & Gaussian & Unipolar & $350 \mathrm{ps}$ & $3.1 \mathrm{kV}$ & $0-10 \mathrm{kHz}$ & Avalanche transistors & FMMT417 & - \\
\hline & $2018[102]$ & Rectangular & Bipolar & $200 \mathrm{~ns}$ to $1 \mu \mathrm{s}$ & $2 \mathrm{kV}$ & $0-1 \mathrm{kHz}$ & MOSFET & - & - \\
\hline & 2019 [69] & Rectangular & Bipolar & $500 \mathrm{~ns}$ to $1 \mathrm{~ms}$ & $15 \mathrm{kV}$ & $10 \mathrm{kHz}$ & MOSFET & C2M0160120D & - \\
\hline & 2019 [29] & Gaussian & Unipolar and bipolar & $8 \mathrm{~ns}$ & $6 \mathrm{kV}$ & $0-3.5 \mathrm{kHz}$ & MOSFET & $\begin{array}{c}\text { IXDD609SI } \\
\text { andC2M0025120D }\end{array}$ & Fixed pulse duration \\
\hline & 2019 [103] & Rectangular & Bipolar & 500 ns to $10 \mathrm{~s}$ & $5 \mathrm{kV}$ & $0-0.5 \mathrm{MHz}$ & MOSFET & - & - \\
\hline & $2020[104]$ & Rectangular & Bipolar & $500 \mathrm{~ns}$ to $5 \mu \mathrm{s}$ & $10 \mathrm{kV}$ & $0-0.5 \mathrm{MHz}$ & MOSFET & C2M0080120 & - \\
\hline & $2020[70]$ & Rectangular & Unipolar & $200 \mathrm{~ns}$ to $1 \mu \mathrm{s}$ & $15.3 \mathrm{kV}$ & $0-10 \mathrm{kHz}$ & MOSFET & C3M0065090J & Integrated with DOS circuit \\
\hline \multirow{8}{*}{ 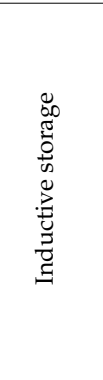 } & 2005 [105] & Gaussian & Unipolar and bipolar & $3.5 \mathrm{~ns}$ & $1.2 \mathrm{kV}$ & $0-100 \mathrm{kHz}$ & MOSFET & APT10035JLL & DOS \\
\hline & 2007 [106] & Gaussian & Unipolar & $20 \mathrm{~ns}$ & $4.5 \mathrm{kV}$ & $20 \mathrm{~Hz}$ & IGBT & СМ300НА- $12 \mathrm{H}$ & $\begin{array}{l}\text { Distorted pulse shape; DOS with } \\
\text { transformers }\end{array}$ \\
\hline & $2007[106]$ & Gaussian & Unipolar & $5 \mathrm{~ns}$ & $7.5 \mathrm{kV}$ & $20 \mathrm{~Hz}$ & MOSFET & APT10035 & - \\
\hline & 2009 [107] & Gaussian & Unipolar & $5 \mathrm{~ns}$ & $4.4 \mathrm{kV}$ & $0-3 \mathrm{MHz}$ & MOSFET & - & Resonant circuit \\
\hline & $2009[107]$ & Gaussian & Unipolar & $2.6 \mathrm{~ns}$ & $1 \mathrm{kV}$ & $0-3 \mathrm{MHz}$ & MOSFET & - & Resonant circuit \\
\hline & $2010[108]$ & Gaussian & Unipolar & $50 \mathrm{~ns}$ & $30 \mathrm{kV}$ & $0-0.5 \mathrm{kHz}$ & Magnetic & - & - \\
\hline & $2012[109]$ & Gaussian & Unipolar & $50 \mathrm{~ns}$ & $1 \mathrm{kV}$ & - & MOSFET & APT37M100L & DOS \\
\hline & 2019 [110] & Rectangular & Unipolar & $23 \mathrm{~ns}$ & $8.2 \mathrm{kV}$ & - & MOSFET & C3M0120090J & Hybrid with Blumlein \\
\hline
\end{tabular}

${ }^{1}$ PCSS - Photoconductive Semiconductor. ${ }^{2}$ JFET - Junction Field Effect Transistor. 


\subsection{Classification of Available In-House Built Generators for nsPEF Electroporation}

It was identified, that the traditional transmission line (including Blumlein-type) pulse forming circuits are no longer dominating in the nsPEF electroporation applications. The progress of semiconductor technologies enabled the development of cost effective, small-size and flexible sub-microsecond generators based on direct capacitor discharge topology. The Marx generator topology with new ultra-fast semiconductor switches forms a new leading technology trend now. In addition, there were few successful attempts to develop resonant-circuit nsPEF generators, which at the end were not followed by other researchers. Unpopularity of this topology is driven by the limited pulse duration flexibility and resulting Gaussian pulse shape.

All topologies demonstrate the possibility to produce high-voltage pulses, however, the transmission line (including Blumlein-type) topologies, which use spark gap switches, demonstrate a possibility to produce very high amplitude (peak voltages exceeding $10 \mathrm{kV}$ ) nsPEF rectangular wave pulses. Yet there is complexity associated with these designs and recent developments of Marx-bank [69,70] and other direct capacitor discharge circuits [71] indicate the growing availability of the off-the-shelf components fulfilling the high-voltage pulse delivery requirements. It is expected that the transmission line topologies will be pushed out of the sub-microsecond range due to a lack of flexibility, requirement of impedance matching and distorted waveforms. These drawbacks are not associated with the reported direct capacitor discharge circuits (including Marx-bank). However, the sub-100 ns pulses in the range of tens of $\mathrm{kV}$ are still yet hardly achievable by the direct capacitor discharge technology.

Indeed, for the high-voltage sub nsPEF pulse delivery, the switch performance and characteristics are crucial. The spark gap switches are fast and cost-effective for nsPEF generation, but these switches have a short lifetime due to electrode erosion, poor pulse duration control and can be frequently associated with turn-on jitter [36]. In contrast, the semiconductor switches offer high flexibility of pulse control, but are more constrained by high-voltage or current withstand limits as well as switch opening and closing times. A series connected switches can solve high-voltage limitation issues, but this increases the stray inductance, which is making the circuit slower.

One of the latest comparison between typical MOSFET, IGBT and bipolar junction transistor (BJT) switches was made in 2019 [72]. It was demonstrated that all three could ensure the breakdown voltage (collector-emitter or drain-source voltage) higher than $1 \mathrm{kV}$. However, the BJT switches, which among all would be the most cost-effective option, are slower than MOSFETs or IGBTs and cannot fulfill the nsPEF pulse forming requirements. It was demonstrated that only the high power MOSFETs can form pulses within the 100-300 ns range with the transition times (rise and fall time) faster than $100 \mathrm{~ns}$ [72]. More than a half of reported nsPEF electroporators (Table 2) use the MOSFET switch as a main pulse forming component.

The review indicates that the direct capacitor discharge topology is taking a lead in the nsPEF applications when the sub-microsecond pulse is required. In addition, the MOSFET switches are now the main technology to produce high-voltage nsPEF pulses in various circuit topologies. The spark gap switches are still applicable in case of a very high-voltage amplitude or ultra-short pulse duration (a few nanoseconds) [64]. Other types of switches (like photoconductive semiconductor, optoelectronic switch or even IGBT) are rarely applicable even if they also provide a capability to deliver ultra-short pulses. In all cases, the transient processes are triggered during the switch turn-on and turn-off, which negatively influence the pulse parameters. The proper compensation circuits must be applied to ensure system protection and the precise pulse waveform with constant pulse rise and fall times independently on the load/electrodes type [111].

\section{Conclusions}

The interest in shorter and higher intensity PEF pulses for electroporation is increasing, which leads to the growing demand for the nsPEF electroporators. Different techniques to design the pulse forming circuits for the nsPEF electroporators exist. Traditionally transmission line circuit topologies 
were used, however, the recent development of SiC MOSFETs have resulted in the new wave of advanced direct capacitor discharge nsPEF electroporators with adjustable pulse parameters.

Author Contributions: Conceptualization, P.B. and V.N.; methodology, P.B.; formal analysis, P.B. and A.M.; investigation, P.B. and A.M; data curation, P.B. and V.N; writing-original draft preparation, P.B. and A.M.; writing-review and editing, P.B. and V.N.; visualization, P.B. and A.M.; supervision, V.N. and S.T. All authors have read and agreed to the published version of the manuscript.

Funding: This research received no external funding.

Acknowledgments: In this section you can acknowledge any support given which is not covered by the author contribution or funding sections. This may include administrative and technical support, or donations in kind (e.g., materials used for experiments).

Conflicts of Interest: The authors declare no conflict of interest.

\section{References}

1. Cemazar, M.; Sersa, G.; Frey, W.; Miklavcic, D.; Teissié, J. Recommendations and Requirements for Reporting on Applications of Electric Pulse Delivery for Electroporation of Biological Samples. Bioelectrochemistry 2018, 122, 69-76. [CrossRef] [PubMed]

2. Denzi, A.; Merla, C.; Palego, C.; Paffi, A.; Ning, Y.; Multari, C.R.; Cheng, X.; Apollonio, F.; Hwang, J.C.M.; Liberti, M. Assessment of Cytoplasm Conductivity by Nanosecond Pulsed Electric Fields. IEEE Trans. Biomed. Eng. 2015, 62, 1595-1603. [CrossRef] [PubMed]

3. Dutta, D.; Asmar, A.; Stacey, M. Effects of Nanosecond Pulse Electric Fields on Cellular Elasticity. Micron 2015, 72, 15-20. [CrossRef] [PubMed]

4. Bennett, W.F.D.; Sapay, N.; Tieleman, D.P. Atomistic Simulations of Pore Formation and Closure in Lipid Bilayers. Biophys. J. 2014, 106, 210-219. [CrossRef] [PubMed]

5. Tsong, T.Y.Y. Electroporation of Cell Membranes. Biophys. J. 1991, 60, 297-306. [CrossRef]

6. Sundararajan, R. Nanosecond Electroporation: Another Look. Mol. Biotechnol. 2009, 41, 69-82. [CrossRef]

7. Miklavčič, D.; Mali, B.; Kos, B.; Heller, R.; Serša, G. Electrochemotherapy: From the Drawing Board into Medical Practice. Biomed. Eng. Online 2014, 13, 29. [CrossRef]

8. Shi, G.; Edelblute, C.; Arpag, S.; Lundberg, C.; Heller, R. IL-12 Gene Electrotransfer Triggers a Change in Immune Response within Mouse Tumors. Cancers 2018, 10, 498. [CrossRef]

9. Sitzmann, W.; Vorobiev, E.; Lebovka, N. Applications of Electricity and Specifically Pulsed Electric Fields in Food Processing: Historical Backgrounds. Innov. Food Sci. Emerg. Technol. 2016, 37, 302-311. [CrossRef]

10. Golberg, A.; Sack, M.; Teissie, J.; Pataro, G.; Pliquett, U.; Saulis, G.; Stefan, T.; Miklavcic, D.; Vorobiev, E.; Frey, W. Energy-Efficient Biomass Processing with Pulsed Electric Fields for Bioeconomy and Sustainable Development. Biotechnol. Biofuels 2016, 9, 94. [CrossRef]

11. Yarmush, M.L.; Golberg, A.; Serša, G.; Kotnik, T.; Miklavčič, D. Electroporation-Based Technologies for Medicine: Principles, Applications, and Challenges. Annu. Rev. Biomed. Eng. 2014, 16, 295-320. [CrossRef] [PubMed]

12. Wagstaff, P.G.K.; Buijs, M.; van den Bos, W.; de Bruin, D.M.; Zondervan, P.J.; de la Rosette, J.J.M.C.H.; Laguna Pes, M.P. Irreversible Electroporation: State of the Art. OncoTargets Ther. 2016, 9, 2437-2446. [CrossRef] [PubMed]

13. Venslauskas, M.S.; Šatkauskas, S. Mechanisms of Transfer of Bioactive Molecules through the Cell Membrane by Electroporation. Eur. Biophys. J. 2015, 44, 277-289. [CrossRef] [PubMed]

14. Miklavčič, D.; Reberšek, M. Development of Devices and Electrodes. In Proceedings of the Electroporation-Based Technologies and Treatments: International Scientific Workshop and Postgraduate Course, Ljubljana, Slovenia, 12-18 November 2017; pp. 85-94.

15. Reberšek, M.; Miklavcic, D. Concepts of Electroporation Pulse Generation and Overview of Electric Pulse Generators for Cell and Tissue Electroporation. In Advanced Electroporation Techniques in Biology and Medicine; CRC Press: Boca Raton, FL, USA, 2010; pp. 323-339.

16. Batista Napotnik, T.; Reberšek, M.; Vernier, P.T.; Mali, B.; Miklavčič, D. Effects of High Voltage Nanosecond Electric Pulses on Eucaryotic Cells (in Vitro): A Systematic Review. Bioelectrochemistry 2016, 110, 1-12. [CrossRef] 
17. Buchmann, L.; Mathys, A. Perspective on Pulsed Electric Field Treatment in the Bio-Based Industry. Front. Bioeng. Biotechnol. 2019, 7, 265. [CrossRef]

18. Kotnik, T.; Rems, L.; Tarek, M.; Miklavčič, D. Membrane Electroporation and Electropermeabilization: Mechanisms and Models. Annu. Rev. Biophys. 2019, 48, 63-91. [CrossRef]

19. Chopinet, L.; Batista-Napotnik, T.; Montigny, A.; Rebersek, M.; Teissié, J.; Rols, M.P.; Miklavčič, D. Nanosecond Electric Pulse Effects on Gene Expression. J. Membr. Biol. 2013, 246, 851-859. [CrossRef]

20. Neal, R.E.; Garcia, P.A.; Robertson, J.L.; Davalos, R.V. Experimental Characterization and Numerical Modeling of Tissue Electrical Conductivity during Pulsed Electric Fields for Irreversible Electroporation Treatment Planning. IEEE Trans. Biomed. Eng. 2012, 59, 1076-1085. [CrossRef]

21. Garcia, P.A.; Rossmeisl, J.H.; Neal, R.E.; Ellis, T.L.; Davalos, R.V. A Parametric Study Delineating Irreversible Electroporation from Thermal Damage Based on a Minimally Invasive Intracranial Procedure. Biomed. Eng. Online 2011, 10, 34. [CrossRef]

22. Mi, Y.; Xu, J.; Tang, X.; Bian, C.; Liu, H.; Yang, Q.; Tang, J. Scaling Relationship of In Vivo Muscle Contraction Strength of Rabbits Exposed to High-Frequency Nanosecond Pulse Bursts. Technol. Cancer Res. Treat. 2018, 17, 1533033818788078. [CrossRef]

23. Guenther, E.; Klein, N.; Mikus, P.; Stehling, M.K.; Rubinsky, B. Electrical Breakdown in Tissue Electroporation. Biochem. Biophys. Res. Commun. 2015, 467, 736-741. [CrossRef] [PubMed]

24. Rodaite-Riseviciene, R.; Saule, R.; Snitka, V.; Saulis, G. Release of Iron Ions from the Stainless Steel Anode Occurring during High-Voltage Pulses and Its Consequences for Cell Electroporation Technology. IEEE Trans. Plasma Sci. 2014, 42, 249-254. [CrossRef]

25. Das, M.; Grider, D.; Leslie, S.; Raju, R.; Schutten, M.; Hefner, A. 10 KV SiC Power MOSFETs and JBS Diodes: Enabling Revolutionary Module and Power Conversion Technologies. In Materials Science Forum; Trans Tech Publications Ltd.: Zurich, Switzerland, 2012.

26. Puc, M.; Čorović, S.; Flisar, K.; Petkovšek, M.; Nastran, J.; Miklavčič, D. Techniques of Signal Generation Required for Electropermeabilization. Survey of Electropermeabilization Devices. Bioelectrochemistry 2004, 64, 113-124. [CrossRef] [PubMed]

27. Pirc, E.; Reberšek, M.; Miklavčič, D. Dosimetry in Electroporation-Based Technologies and Treatments. In Dosimetry in Bioelectromagnetics; Markov, M., Ed.; CRC Press: Boca Raton, FL, USA, 2017; pp. $233-268$.

28. Lucia, O.; Sarnago, H.; Garcia-Sanchez, T.; Mir, L.M.; Burdio, J.M. Industrial Electronics for Biomedicine: A New Cancer Treatment Using Electroporation. IEEE Ind. Electron. Mag. 2019, 13, 6-18. [CrossRef]

29. Pirc, E.; Miklavčič, D.; Reberšek, M. Nanosecond Pulse Electroporator With Silicon Carbide MOSFETs: Development and Evaluation. IEEE Trans. Biomed. Eng. 2019, 66, 3526-3533. [CrossRef]

30. Elgenedy, M.A.; Massoud, A.M.; Ahmed, S.; Williams, B.W.; McDonald, J.R. A Modular Multilevel Voltage-Boosting Marx Pulse-Waveform Generator for Electroporation Applications. IEEE Trans. Power Electron. 2019, 34, 10575-10589. [CrossRef]

31. Sack, M. Marx-Generator Design and Development for Biomass Electroporation. In Handbook of Electroporation; Springer International Publishing: Cham, Switzerland, 2017; pp. 793-812.

32. Elserougi, A.; Massoud, A.; Ahmed, S. Conceptual Study of a Bipolar Modular High Voltage Pulse Generator with Sequential Charging. IEEE Trans. Dielectr. Electr. Insul. 2016, 23, 3450-3457. [CrossRef]

33. Stankevic, V.; Simonis, P.; Zurauskiene, N.; Stirke, A.; Dervinis, A.; Bleizgys, V.; Kersulis, S.; Balevicius, S. Compact Square-Wave Pulse Electroporator with Controlled Electroporation Efficiency and Cell Viability. Symmetry (Basel) 2020, 12, 412. [CrossRef]

34. Bernal, C.; Lucia, O.; Sarnago, H.; Burdio, J.M.; Ivorra, A.; Castellvi, Q. A Review of Pulse Generation Topologies for Clinical Electroporation. In Proceedings of the IECON 2015-41st Annual Conference of the IEEE Industrial Electronics Society, Yokohama, Japan, 9-12 November 2015; pp. 625-630.

35. Elgenedy, M.A.; Massoud, A.M.; Ahmed, S.; Williams, B.W. A High-Gain, High-Voltage Pulse Generator Using Sequentially Charged Modular Multilevel Converter Submodules, for Water Disinfection Applications. IEEE J. Emerg. Sel. Top. Power Electron. 2018, 6, 1394-1406. [CrossRef]

36. Xiao, S.; Zhou, C.; Yang, E.; Rajulapati, S.R. Nanosecond Bipolar Pulse Generators for Bioelectrics. Bioelectrochemistry 2018, 123, 77-87. [CrossRef] 
37. Butkus, P.; Tolvaisiene, S. The Comparison of Technical Capabilities of Six Pulse Generators for Biological Applications. In Proceedings of the 2019 IEEE 7th IEEE Workshop on Advances in Information, Electronic and Electrical Engineering (AIEEE), Liepaja, Latvia, 15-16 November 2019; Institute of Electrical and Electronics Engineers (IEEE): Piscataway, NJ, USA, 2020; pp. 1-4.

38. Rebersek, M.; Miklavcic, D. Advantages and Disadvantages of Different Concepts of Electroporation Pulse Generation. ATKAFF 2011, 52, 11-19. [CrossRef]

39. Redondo, L.M.S. Basic Concepts of High-Voltage Pulse Generation. In Handbook of Electroporation; Springer International Publishing: Cham, Switzerland, 2017; Volume 2, pp. 859-879.

40. Behrend, M.; Kuthi, A.; Gu, X.; Vernier, P.T.; Marcu, L.; Craft, C.M.; Gundersen, M.A. Pulse Generators for Pulsed Electric Field Exposure of Biological Cells and Tissues. IEEE Trans. Dielectr. Electr. Insul. 2003, 10, 820-825. [CrossRef]

41. Reberšek, M.; Miklavčič, D.; Bertacchini, C.; Sack, M. Cell Membrane Electroporation-Part 3: The Equipment. IEEE Electr. Insul. Mag. 2014, 30, 8-18. [CrossRef]

42. Joshi, R.P.; Schoenbach, K.H. Bioelectric Effects of Intense Ultrashort Pulses. Crit. Rev. Biomed. Eng. 2010, 38, 255-304.

43. Schmitt, M.A.; Friedrich, O.; Gilbert, D.F. Portoporator (C): A Portable Low-Cost Electroporation Device for Gene Transfer to Cultured Cells in Biotechnology, Biomedical Research and Education. Biosens. Bioelectron. 2019, 131, 95-103. [CrossRef]

44. Rubin, A.E.; Levkov, K.; Usta, O.B.; Yarmush, M.; Golberg, A. IGBT-Based Pulsed Electric Fields Generator for Disinfection: Design and In Vitro Studies on Pseudomonas Aeruginosa. Ann. Biomed. Eng. 2019, 47, 1314-1325. [CrossRef]

45. Ping, W.; Jiali, B.; Hong, W.; Huiping, W. Multi-Pulse Generator for Electroporation. In Proceedings of the Annual International Conference of the IEEE Engineering in Medicine and Biology, Cancun, Mexico, 17-21 September 2003.

46. Elserougi, A.A.; Massoud, A.M.; Ahmed, S. A Modular High-Voltage Pulse-Generator with Sequential Charging for Water Treatment Applications. IEEE Trans. Ind. Electron. 2016, 63, 7898-7907. [CrossRef]

47. Camp, J.T.; Xiao, S.; Schoenbach, K.H. Development of a High Voltage, 150 Ps Pulse Generator for Biological Applications. In Proceedings of the 2008 IEEE International Power Modulators and High Voltage Conference, PMHVC, Las Vegas, NV, USA, 27-31 May 2008; pp. 338-341.

48. Foshee, W.G.; Kirkici, H.; Hung, J.Y.; Blythe, E.K.; Goel, A.; Wehtje, G.R. Seedling Emergence of Smallflower Morningglory and Green Foxtail Subjected to a Pulsed Electric Field. Int. J. Veg. Sci. 2007, 13, 61-72. [CrossRef]

49. Hahn, U.; Herrmann, M.; Leipold, F.; Schoenbach, K.H. Nanosecond, Kilovolt Pulse Generators. In Proceedings of the PPPS 2001-Pulsed Power Plasma Science 2001, Las Vegas, NV, USA, 17-22 June 2001; Institute of Electrical and Electronics Engineers Inc.: Piscataway, NJ, USA, 2001; Volume 2, pp. 1575-1578.

50. Sack, M.; Sigler, J.; Frenzel, S.; Eing, C.; Arnold, J.; Michelberger, T.; Frey, W.; Attmann, F.; Stukenbrock, L.; Müller, G. Research on Industrial-Scale Electroporation Devices Fostering the Extraction of Substances from Biological Tissue. Food Eng. Rev. 2010, 2, 147-156. [CrossRef]

51. Sack, M.; Mueller, G. Design Considerations for Electroporation Reactors. IEEE Trans. Dielectr. Electr. Insul. 2017, 24, 1992-2000. [CrossRef]

52. Sack, M.; Sigler, J.; Eing, C.; Stukenbrock, L.; Stängle, R.; Wolf, A.; Müller, G. Operation of an Electroporation Device for Grape Mash. IEEE Tran. Plasma Sci. 2010, 38, 1928-1934. [CrossRef]

53. Muratori, C.; Pakhomov, A.G.; Xiao, S.; Pakhomova, O.N. Electrosensitization Assists Cell Ablation by Nanosecond Pulsed Electric Field in 3D Cultures. Sci. Rep. 2016, 6, 23225. [CrossRef] [PubMed]

54. Wandel, A.; Ben-David, E.; Ulusoy, B.S.; Neal, R.; Faruja, M.; Nissenbaum, I.; Gourovich, S.; Goldberg, S.N. Optimizing Irreversible Electroporation Ablation with a Bipolar Electrode. J. Vasc. Interv. Radiol. 2016, 27, 1441-1450.e2. [CrossRef] [PubMed]

55. Kurcevskis, S.; Grainys, A.; Tolvaisiene, S.; Ustinavicius, T. High Power Electroporation System in Food Treatment-Review. In Proceedings of the 2019 IEEE 7th IEEE Workshop on Advances in Information, Electronic and Electrical Engineering (AIEEE), Liepaja, Latvia, 15-16 November 2019; Institute of Electrical and Electronics Engineers (IEEE): Piscataway, NJ, USA, 2020; pp. 1-4. 
56. Cronjé, T.F.; Gaynor, P.T. High Voltage and Frequency Bipolar Pulse Generator Design for Electroporation-Based Cancer Therapy. In Proceedings of the 2013 Australasian Universities Power Engineering Conference, AUPEC 2013, Hobart, TAS, Australia, 29 September-3 October 2013; pp. 1-7.

57. Abdelsalam, I.; Elgenedy, M.A.; Ahmed, S.; Williams, B.W. Full-Bridge Modular Multilevel Submodule-Based High-Voltage Bipolar Pulse Generator with Low-Voltage DC, Input for Pulsed Electric Field Applications. IEEE Trans. Plasma Sci. 2017, 45, 2857-2864. [CrossRef]

58. Dong, S.; Yao, C.; Mi, Y.; Li, C.; Zhao, Y.; Lv, Y.; Liu, H. Design of Bipolar Pulse Generator Topology Based on Marx Supplied by Double Power. In Proceedings of the 2016 IEEE International Power Modulator and High Voltage Conference, IPMHVC 2016, San Francisco, CA, USA, 6-9 July 2017; Institute of Electrical and Electronics Engineers Inc.: Piscataway, NJ, USA, 2017; pp. 26-31.

59. Deshpande, A.; Prakash, G.V.; Goswami, U.; Singh, R.; Anitha, V.P. Implementation of Line Type High Voltage Nanosecond Rectangular Pulse Generator with Adjustable Pulse Widths for Liquid Discharge Applications. In Proceedings of the IEEE International Pulsed Power Conference, Orlando, FL, USA, 23-29 June 2019; Institute of Electrical and Electronics Engineers Inc.: Piscataway, NJ, USA, 2019.

60. Mi, Y.; Zhang, Y.; Wan, J.; Yao, C.; Li, C. Nanosecond Pulse Generator Based on an Unbalanced Blumlein-Type Multilayered Microstrip Transmission Line and Solid-State Switches. IEEE Trans. Plasma Sci. 2016, 44, 795-802. [CrossRef]

61. Mi, Y.; Wan, J.; Bian, C.; Zhang, Y.; Yao, C.; Li, C. A Multiparameter Adjustable, Portable High-Voltage Nanosecond Pulse Generator Based on Stacked Blumlein Multilayered PCB Strip Transmission Line. IEEE Trans. Plasma Sci. 2016, 44, 2022-2029. [CrossRef]

62. Mi, Y.; Bian, C.; Wan, J.; Xu, J.; Yao, C.; Li, C. A Modular Solid-State Nanosecond Pulsed Generator Based on Blumlein-Line and Transmission Line Transformer with Microstrip Line. IEEE Trans. Dielectr. Electr. Insul. 2017, 24, 2196-2202. [CrossRef]

63. Romeo, S.; D'Avino, C.; Zeni, O.; Zeni, L. A Blumlein-Type, Nanosecond Pulse Generator with Interchangeable Transmission Lines for Bioelectrical Applications. IEEE Trans. Dielectr. Electr. Insul. 2013, 20, 1224-1230. [CrossRef]

64. Kolb, J.F.; Kono, S.; Schoenbach, K.H. Nanosecond Pulsed Electric Field Generators for the Study of Subcellular Effects. Bioelectromagnetics 2006, 27, 172-187. [CrossRef]

65. Warindi, H.S.P.; Suharyanto, H.G. Impedance Measurement System of a Biological Material Undergoing Pulsed Electric Field Exposed. In Procedia Engineering; Elsevier Ltd.: Amsterdam, The Netherlands, 2017; Volume 170, pp. 410-415.

66. Rebersek, M.; Kranjc, M.; Pavliha, D.; Batista-Napotnik, T.; Vrtanik, D.; Amon, S.; Miklavi, D. Blumlein Configuration for High-Repetition-Rate Pulse Generation of Variable Duration and Polarity Using Synchronized Switch Control. IEEE Trans. Biomed. Eng. 2009, 56, 2642-2648. [CrossRef]

67. Lindblom, A. Inductive Pulse Generation. Digit. Compr. Summ. Uppsala Diss. Fac. Sci. Technol. 2006, 159, 93.

68. Darwish, A.; Elgenedy, M.A.; Finney, S.J.; Williams, B.W.; McDonald, J.R. A Step-up Modular High-Voltage Pulse Generator Based on Isolated Input-Parallel/Output-Series Voltage-Boosting Modules and Modular Multilevel Submodules. IEEE Trans. Ind. Electron. 2019, 66, 2207-2216. [CrossRef]

69. Liu, Y.; Fan, R.; Zhang, X.; Tu, Z.; Zhang, J. Bipolar High Voltage Pulse Generator without H-Bridge Based on Cascade of Positive and Negative Marx Generators. IEEE Trans. Dielectr. Electr. Insul. 2019, 26, 476-483. [CrossRef]

70. Zeng, W.; Yao, C.; Dong, S.; Wang, Y.; Ma, J.; He, Y.; Yu, L. Self-Triggering High-Frequency Nanosecond Pulse Generator. IEEE Trans. Power Electron. 2020, 35, 8002-8012. [CrossRef]

71. Novickij, V.; Stankevic, V.; Zurauskiene, N.; Balevicius, S.; Stirke, A.; Dervinis, A.; Bleizgys, V. Nanosecond Square-Wave Pulse Generator for Pulsed Electric Field Treatment of Biological Objects. In Proceedings of the 5th Euro-Asian Pulsed Power Conference, Kumamoto, Japan, 8-12 September 2014; pp. 157-160.

72. Davies, I.W.; Merla, C.; Casciati, A.; Tanori, M.; Zambotti, A.; Mancuso, M.; Bishop, J.; White, M.; Palego, C.; Hancock, C.P. Push-Pull Configuration of High-Power MOSFETs for Generation of Nanosecond Pulses for Electropermeabilization of Cells. Int. J. Microw. Wirel. Technol. 2019, 11, 645-657. [CrossRef]

73. Deng, J.; Stark, R.H.; Schoenbach, K.H. Nanosecond Pulse Generator for Intracellular Electromanipulation. In Proceedings of the IEEE Conference Record of Power Modulator Symposium IEEE, Norfolk, VA, USA, 26-29 June 2000; pp. 47-50. 
74. Kolb, J.F.; Scarlett, S.; Cannone, J.; Zhuang, J.; Osgood, C.; Schoenbach, K.H.; De Angelis, A.; Zeni, L. Nanosecond Pulse Generator with Variable Pulse Duration for the Study of Pulse Induced Biological Effects. In Proceedings of the 2008 IEEE International Power Modulators and High-Voltage Conference, Las Vegas, NV, USA, 28-31 May 2008; pp. 61-64.

75. Pavliha, D.; Reberšek, M.; Miklavčič, D. Design and Quality Assessment of the Graphical User Interface Software of a High-Voltage Signal Generator. Elektroteh. Vestn. 2011, 78, 281-286.

76. Chuan, L.; Wenchuan, W.; Lin, Z.; Mingjia, L.; Jianhua, Z. Development of 650 KV 2 Ns High Voltage Pulse Generator. High Power Laser Part. Beams 2014, 26, 3-7.

77. Mi, Y.; Bian, C.; Li, P.; Yao, C.; Li, C. A Modular Generator of Nanosecond Pulses with Adjustable Polarity and High Repetition Rate. IEEE Trans. Power Electron. 2018, 33, 10654-10662. [CrossRef]

78. Achour, Y.; Starzyński, J.; Kasprzycka, W.; Trafny, E.A. Compact Low-Cost High-Voltage Pulse Generator for Biological Applications. Int. J. Circuit Theory Appl. 2019, 47, 1948-1962. [CrossRef]

79. He, Y.; Ma, J.; Yu, L.; Dong, S.; Gao, L.; Zeng, W.; Yao, C. 10 MHz High-Power Pulse Generator on Boost Module. IEEE Trans. Ind. Electron. 2020. [CrossRef]

80. Merla, C.; El Amari, S.; Kenaan, M.; Liberti, M.; Apollonio, F.; Arnaud-Cormos, D.; Couderc, V.; Leveque, P. A 10- $\Omega$ High-Voltage Nanosecond Pulse Generator. IEEE Trans. Microw. Theory Tech. 2010, 58, 4079-4085. [CrossRef]

81. Balevicius, S.; Stankevic, V.; Zurauskiene, N.; Shatkovskis, E.; Stirke, A.; Bitinaite, A.; Saule, R.; Maciuleviciene, R.; Saulis, G. System for the Nanoporation of Biological Cells Based on an Optically-Triggered High-Voltage Spark-Gap Switch. IEEE Trans. Plasma Sci. 2013, 41, 2706-2711. [CrossRef]

82. Chaney, A.; Sundararajan, R. Simple MOSFET-Based High-Voltage Nanosecond Pulse Circuit. IEEE Trans. Plasma Sci. 2004, 32, 1919-1924. [CrossRef]

83. Yao, C.; Sun, C.; Mi, Y.; Xiong, L.; Wang, S. Experimental Studies on Killing and Inhibiting Effects of Steep Pulsed Electric Field (SPEF) to Target Cancer Cell and Solid Tumor. IEEE Trans. Plasma Sci. 2004, 32, 1626-1633. [CrossRef]

84. Sunkam, R.K.; Selmic, R.R.; Haynie, D.T.; Hill, J.S. Solid-State Nanopulse Generator: Application in Ultra-Wideband Bioeffects Research. In Proceedings of the Conference Proceedings-IEEE Southeastcon, Greensboro, NC, USA, 26-29 March 2004; pp. 281-284.

85. Leveque, P.; Arnaud-Cormos, D. Generators and Applicators for Nanosecond Pulsed Electric Field. In Proceedings of the 6th European Conference on Antennas and Propagation, EuCAP 2012, Prague, Czech Republic, 26-30 March 2012; pp. 351-355.

86. Krishnaveni, R.S.; Veeraraghavalu, R.; Rangarajan, R. Development of Pef Source in Nanosecond Range for Food Sterilization. J. Electr. Syst. 2015, 11, 407-419.

87. Novickij, V.; Grainys, A.; Butkus, P.; Tolvaišienè, S.; Švedienė, J.; Paškevičius, A.; Novickij, J. High-Frequency Submicrosecond Electroporator. Biotechnol. Biotechnol. Equip. 2016, 30, 607-613. [CrossRef]

88. Zajc, A.; Miklavcic, D.; Rebersek, M. Expanding the Power Pulse Duration Range for Electroporation. In Proceedings of the 28th International Conference Electrotechnical and Computer Science, Portorož, Slovenia, 23-24 September 2019.

89. Krishnaswamy, P.; Kuthi, A.; Vernier, P.T.; Gundersen, M.A. Compact Subnanosecond Pulse Generator Using Avalanche Transistors for Cell Electroperturbation Studies. IEEE Transa. Dielectr. Electr. Insul. 2007, 14, 871-877. [CrossRef]

90. Mendes, J.P.M.; Canacsinh, H.; Redondo, L.M.; Rossi, J.O. Solid State Marx Modulator with Blumlein Stack for Bipolar Pulse Generation. IEEE Trans. Dielectr. Electr. Insul. 2011, 18, 1199-1204. [CrossRef]

91. Yao, C.; Zhang, X.; Guo, F.; Dong, S.; Mi, Y.; Sun, C. FPGA-Controlled All-Solid-State Nanosecond Pulse Generator for Biological Applications. IEEE Trans. Plasma Sci. 2012, 40, 2366-2372. [CrossRef]

92. Sakamoto, T.; Akiyama, H. Solid-State Dual Marx Generator with a Short Pulsewidth. IEEE Trans. Plasma Sci. 2013, 41, 2649-2653. [CrossRef]

93. Yao, C.; Zhao, Z.; Dong, S.; Zuo, Z. High-Voltage Subnanosecond Pulsed Power Source with Repetitive Frequency Based on Marx Structure. IEEE Trans. Dielectr. Electr. Insul. 2015, 22, 1896-1901. [CrossRef]

94. Dong, S.; Yao, C.; Yang, N.; Luo, T.; Zhou, Y.; Wang, C. Solid-State Nanosecond-Pulse Plasma Jet Apparatus Based on Marx Structure with Crowbar Switches. IEEE Trans. Plasma Sci. 2016, 44, 3353-3360. [CrossRef] 
95. Li, C.; Zhang, R.; Yao, C.; Mi, Y.; Tan, J.; Dong, S.; Gong, L. Development and Simulation of a Compact Picosecond Pulse Generator Based on Avalanche Transistorized Marx Circuit and Microstrip Transmission Theory. IEEE Trans. Plasma Sci. 2016, 44, 1907-1913. [CrossRef]

96. Redondo, L.M.; Kandratsyeu, A.; Barnes, M.J.; Calatroni, S.; Wuensch, W. Solid-State Marx Generator for the Compact Linear Collider Breakdown Studies. In Proceedings of the 2016 IEEE International Power Modulator and High Voltage Conference, IPMHVC 2016, San Francisco, CA, USA, 6-9 July 2016; Institute of Electrical and Electronics Engineers Inc.: Piscataway, NJ, USA, 2017; pp. 187-192.

97. Yao, C.; Dong, S.; Zhao, Y.; Mi, Y.; Li, C. A Novel Configuration of Modular Bipolar Pulse Generator Topology Based on Marx Generator with Double Power Charging. IEEE Trans. Plasma Sci. 2016, 44, 1872-1878. [CrossRef]

98. Yao, C.; Dong, S.; Zhao, Y.; Zhou, Y.; Mi, Y.; Li, C. High-Frequency Composite Pulse Generator Based on Full-Bridge Inverter and Soft Switching for Biological Applications. IEEE Trans. Dielectr. Electr. Insul. 2016, 23, 2730-2737. [CrossRef]

99. Li, C.; Wang, E.; Yao, C.; Mi, Y.; Tan, J.; Zhang, R. Compact Solid-State Marx-Bank Sub-Nanosecond Pulse Generator Based on Gradient Transmission Line Theory. IEEE Trans. Dielectr. Electr. Insul. 2017, 24, 2181-2188. [CrossRef]

100. Garner, A.L.; Caiafa, A.; Jiang, Y.; Klopman, S.; Morton, C.; Torres, A.S.; Loveless, A.M.; Neculaes, V.B. Design, Characterization and Experimental Validation of a Compact, Flexible Pulsed Power Architecture for Ex Vivo Platelet Activation. PLoS ONE 2017, 12, e0181214. [CrossRef]

101. Li, C.; Wang, E.; Tan, J.; Zhang, R.; Wang, S.; Yao, C.; Mi, Y. Design and Development of a Compact All-Solid-State High-Frequency Picosecond-Pulse Generator. IEEE Trans. Plasma Sci. 2018, 46, 3249-3256. [CrossRef]

102. Ke, Q.; Li, C.; Yao, C.; Du, J.; Yao, C.; Mi, Y. Development of Bipolar Nano/Microsecond Pulse Generator. In Proceedings of the 2018 IEEE International Power Modulator and High Voltage Conference, IPMHVC, Jackson, WY, USA, 3-7 June 2018; Institute of Electrical and Electronics Engineers Inc.: Piscataway, NJ, USA, 2018; pp. 13-16.

103. Redondo, L.M.; Zahyka, M.; Kandratsyeu, A. Solid-State Generation of High-Frequency Burst of Bipolar Pulses for Medical Applications. IEEE Trans. Plasma Sci. 2019, 47, 4091-4095. [CrossRef]

104. Zeng, W.; Yu, L.; Dong, S.; Ma, J.; Wang, Y.; He, Y.; Wang, X.; Yao, C. A Novel High Frequency Bipolar Pulsed Power Generator for Biological Applications. IEEE Trans. Power Electron. 2020. [CrossRef]

105. Kuthi, A.; Gabrielsson, P.; Behrend, M.R.; Vernier, P.T.; Gundersen, M.A. Nanosecond Pulse Generator Using Fast Recovery Diodes for Cell Electromanipulation. IEEE Trans. Plasma Sci. 2005, 33, 1192-1197. [CrossRef]

106. Tang, T.; Wang, F.; Kuthi, A.; Gundersen, M. Nanosecond Pulse Generator Using Diode Opening Switch for Cell Electroperturbation Studies. In Proceedings of the Digest of Technical Papers-IEEE International Pulsed Power Conference, Monterey, CA, USA, 13-15 June 2007; pp. 1258-1261.

107. Sanders, J.M.; Kuthi, A.; Wu, Y.H.; Vernier, P.T.; Gundersen, M.A. A Linear, Single-Stage, Nanosecond Pulse Generator for Delivering Intense Electric Fields to Biological Loads. IEEE Trans. Dielectr. Electr. Insul. 2009, 16, 1048-1054. [CrossRef]

108. Akiyama, M.; Sakugawa, T.; Hosseini, S.H.R.; Shiraishi, E.; Kiyan, T.; Akiyama, H. High-Performance Pulsed-Power Generator Controlled by FPGA. IEEE Trans. Plasma Sci. 2010, 38, 2588-2592. [CrossRef]

109. Kranjc, M.; Rebersek, M.; Miklavcic, D. Numerical Simulations Aided Development of Nanosecond Pulse Electroporators. In Proceedings of the 6th European Conference on Antennas and Propagation, EuCAP 2012, Prague, Czech Republic, 26-30 March 2012; pp. 344-347.

110. Ma, J.; Dong, S.; Liu, H.; Yu, L.; Yao, C. A High-Gain Nanosecond Pulse Generator Based on Inductor Energy Storage and Pulse Forming Line Voltage Superposition. In Proceedings of the IEEE International Pulsed Power Conference, Orlando, FL, USA, 23-29 June 2019; Institute of Electrical and Electronics Engineers Inc.: Piscataway, NJ, USA, 2019.

111. Dermol-Černe, J.; Pirc, E.; Miklavčič, D. Mechanistic View of Skin Electroporation-Models and Dosimetry for Successful Applications: An Expert Review. Exp. Opin. Drug Deliv. 2020, 17, 689-704. [CrossRef] 